\title{
Metástasis cervical contralateral en el carcinoma epidermoide de la cavidad oral. Estudio clínico analítico retrospectivo en 315 pacientes primariamente tratados con cirugía
}

\author{
Contralateral neck metastasis in squamous cell carcinoma of the oral cavity. \\ An analytical retrospective clinical study of 315 patients primarily treated with
} surgery

\author{
R. González-García, L. Naval-Gías, FJ. Rodríguez-Campo, J. Sastre-Pérez, MF. Muñoz-Guerra, \\ FJ. Díaz-González
}

\begin{abstract}
Resumen: Objetivos. Existen en la literatura numerosos estudios en relación con los factores pronósticos implicados en la aparición de metástasis cervicales ipsilaterales en el carcinoma epidermoide de cavidad oral. Sin embargo, no existen estudios clínicos amplios acerca de la asociación de factores clínico-patológicos y la aparición de metástasis cervicales contralaterales tras la resección quirúrgica del tumor primario. El propósito de este estudio es el análisis de los factores implicados en la aparición de metástasis cervical contralateral en pacientes con carcinoma epidermoide de cavidad oral primariamente tratados con cirugía.

Pacientes y métodos. Se analizó una serie de 315 pacientes consecutivos con carcinoma epidermoide de la cavidad oral no tratados previamente. Se realizó un estudio complementario del subgrupo de 203 pacientes con carcinoma epidermoide del borde lateral de la lengua libre, por tratarse de un grupo muy prevalente en la serie analizada. Todos los pacientes recibieron tratamiento quirúrgico con o sin tratamiento radioterápico adyuvante. Varias fueron las variables clínicas e histopatológicas analizadas, como son: las características clínicas del tumor, el estadio tumoral, el grado de diferenciación histológica, el tipo de disección cervical, la supervivencia enfermedad-específica, los márgenes quirúrgicos en la pieza resecada, la extensión ganglionar extracapsular, la diseminación perineural y la afectación ósea. Resultados. La duración media del seguimiento de los pacientes que sobrevivieron fue de 70,9 $\pm 49,6$ meses. Ochenta y tres pacientes murieron a causa de la enfermedad a lo largo del seguimiento. Cuarenta y siete de estos pertenecían al subgrupo de pacientes con carcinoma epidermoide de lengua. Un total de 147 pacientes permanecía vivo sin evidencias de recurrencia de la enfermedad al final del periodo de seguimiento, 116 de los cuales correspondían al subgrupo de pacientes con carcinoma epidermoide de lengua.
\end{abstract}

Servicio de Cirugía Oral y Maxilofacial.

Hospital Universitario La Princesa. Madrid. España

\section{Correspondencia:}

R. González García

Hospital Universitario La Princesa

Servicio de Cirugía Oral y Maxilofacial

Diego de León, 62

28006 Madrid, España.

Email: gonzalez-garcia@hotmail.com
Abstract: Objectives. There are numerous studies in the literature on the prognostic factors involved in the appearance of ipsilateral neck metastasis in squamous cell carcinoma of the oral cavity. However, there are no extensive clinical studies on the association of clinicopathological factors and the appearance of contralateral neck metastasis after the surgical resection of the primary tumor. The object of this study is to analyze the factors implied in the appearance of contralateral neck metastasis in patients with squamous cell carcinoma of the oral cavity treated primarily with surgery.

Patients and methods. A series of 315 consecutive patients with squamous cell carcinoma of the oral cavity, who had not been treated previously, were analyzed. A complementary study of a subgroup of 203 patients with squamous cell carcinoma of the lateral border of the mobile tongue was carried out, as this was a very prevalent group in the series analyzed. The patients all received surgical treatment with or without adjuvant radiotherapy treatment. Various clinical and histopathological variables were analyzed, such as the clinical characteristics of the tumor, tumor stage, degree of histological differentiation, type of neck dissection, disease-specific survival, surgical margins of the resected specimen, extracapsular lymph node extension, perineural dissemination and bone involvement.

Results. The mean follow-up of patients who survived was $70.9 \pm$ 49.6 months. Eighty-three patients died as a result of the disease during the follow-up period. Forty-six of these belonged to the subgroup of patients with squamous cell carcinoma of the tongue. A total of 147 patients remained alive with no evidence of disease recurrence at the end of the follow-up period, 116 of whom corresponded to the subgroup of patients with squamous cell carcinoma of the tongue. The mean rate of disease-free survival was $147 \pm 6$ months. Twenty-nine (9.1\%) of patients developed ipsilateral neck recurrence, while 18 (5.69\%) showed contralateral neck recurrence. For patients with squamous cell carcinoma of the tongue, and considering the percentages in relation to the 203 patients with this entity, these figures were 20 (9.8\%) and 9 (4.4\%) 
El tiempo de supervivencia medio libre de enfermedad fue $147 \pm 6$ meses. Veintinueve $(9,1 \%)$ pacientes desarrollaron recurrencia cervical ipsilateral, mientras que $18(5,69 \%)$ mostraron recurrencia cervical contralateral. Para los pacientes con carcinoma epidermoide de lengua, y considerando los porcentajes en relación a los 203 pacientes con esta entidad, estas cifras fueron de $20(9,8 \%)$ y $9(4,4 \%)$, respectivamente. El tiempo medio de aparición de las metástasis cervicales desde la cirugía fue de 12,52 meses (rango: 3-49), algo menor para el subgrupo de pacientes con carcinoma epidermoide de lengua (11,4 meses, rango: 3-27). Dieciocho de los 29 pacientes con recurrencia cervical ipsilateral murieron finalmente de la enfermedad. Siete de 18 pacientes con metástasis contralateral murieron igualmente de la enfermedad. En el subgrupo de pacientes con carcinoma epidermoide de lengua, estas cifras fueron: catorce de 20 pacientes con metástasis cervical ipsilateral y ocho de 9 pacientes con metástasis cervical contralateral. Varios factores clínicopatológicos mostraron asociación estadísticamente significativa $(p<0,05)$ con respecto a la aparición de metástasis cervical contralateral, como: tiempo hasta el diagnóstico, estadio tumoral, diferenciación histopatológica, márgenes quirúrgicos en la resección del tumor primario, espesor tumoral, tipo de disección cervical e infiltración perineural. Por el contrario, el estadio N clínico ipsilateral no mostró una asociación estadísticamente significativa en el subgrupo de pacientes con carcinoma epidermoide de lengua llibre, y sí lo hicieron el grado histológico tumoral y la inflamación peritumoral.

Conclusiones. La demora de 12 meses o más en el diagnóstico de carcinoma epidermoide de cavidad oral se asocia a un riesgo aumentado de metástasis cervical contralateral. Otros factores predictivos de la aparición de metástasis cervical contralateral son el estadio tumoral IV de la clasificación TNM, la pobre diferenciación histopatológica del tumor primario, la presencia de márgenes quirúrgicos menores de $1 \mathrm{~cm}$ en la pieza de resección del tumor primario, la realización de disección cervical funcional ipsilateral de modo aislado y la afectación perineural. La presencia de adenopatías cervicales ipsilaterales clínicamente positivas en el momento del diagnóstico se asocia con una incidencia aumentada de recurrencia cervical contralateral en el carcinoma epidermoide de cavidad oral. La aparición de la mayoría de los casos de recurrencia cervical contralateral en los dos años siguientes a la cirugía, hace precisa la realización de un seguimiento estrecho de estos pacientes.

Palabras clave: Carcinoma epidermoide; Cavidad oral; Lengua; Metástasis cervical.

Recibido: 12.07.2006

Aceptado: 16.06 .2008

\section{Introducción}

Numerosos factores clínicos y patológicos han sido considerados pronósticos de aparición de recurrencia cervical en el carcinoma epidermoide de la cavidad oral, como la localización del tumor primario, el tamaño tumoral, el estadio tumoral, el grado de diferenciación histológica, el espesor tumoral y la invasión perineural. ${ }^{1-3}$ De igual modo, se ha demostrado asociación entre la aparición de recurrencia cervical y mal pronóstico. ${ }^{4}$ Más aún, la aparición de recurrencia cervical tras la realización de disección cervical radical tiene casi invariablemente una evolución nefasta. ${ }^{5}$

Tradicionalmente, el carcinoma epidermoide de la cavidad oral localizado en la línea media ha sido asociado con una tasa mayor respectively. The mean time it took for neck metastasis to appear following surgery was 12.52 months (range 3-49), somewhat less for the subgroup of patients with squamous cell carcinoma of the tongue (11.4 months, range 3-27). Eighteen of the 29 patients with ipsilateral neck recurrence finally died of the disease. Seven of the 18 patients with contralateral metastasis also died of the disease. In the subgroup of patients with squamous cell carcinoma of the tongue these figures were: 14 of the 20 patients with ipsilateral neck metastasis and eight of the nine patients with contralateral neck metastasis. Various clinicopathological factors showed an association that was statistically significant $(p<0.05)$ with regard to the appearance of contralateral neck metastasis such as: time until diagnosis, tumor stage, histopathological differentiation, surgical margins with regard to primary tumor resection, tumor thickness, type of neck dissection and perineural infiltration. Only the ipsilateral clinical N stage showed a statistically significant association $(p<0.05)$ in the subgroup of patients with squamous cell carcinoma of the mobile tongue.

Conclusion. A delay of 12 months or more in the diagnosis of squamous cell carcinoma of the oral cavity is associated with an increased risk of contralateral neck metastasis. Other predictive factors for the appearance of contralateral neck metastasis are stage IV tumor by TNM classification, the poor histopathological differentiation of the primary tumor, the presence of surgical margins of less than $1 \mathrm{~cm}$ in the resection specimen of the primary tumor, carrying out ipsilateral functional neck dissection in an isolated fashion and perineural involvement. The presence of ipsilateral neck nodes that are clinically positive at diagnosis is associated with an increased incidence of contralateral neck recurrence of squamous cell carcinoma of the oral cavity and mobile tongue. The appearance in most cases of contralateral neck recurrence in the two years after surgery, implied that carrying out a close following of these patients is necessary.

Key words: Squamous cell carcinoma; Oral cavity; Tongue; Neck metastasis.

\section{Introduction}

Numerous clinical and pathological factors have been considered as prognostic factors in neck recurrence of squamous cell carcinoma of the oral cavity, such as the location of the primary tumor, tumor size, stage, degree of histological differentiation, tumor thickness and perineural invasion..$^{1-3}$ Similarly, the appearance of recurrence in the neck after radical neck dissection invariably proves fatal. ${ }^{5}$

Traditionally, squamous cell carcinoma of the oral cavity that is located in the midline has been associated with an increased rate of bilateral and contralateral neck metastasis. ${ }^{6}$ This applies to the different sites: tongue, alveolar gin- 
de metástasis cervical bilateral y contralateral. ${ }^{6}$ Esta afirmación es extensible a sus diferentes localizaciones: lengua, encía alveolar, mucosa bucal y suelo de la boca. Con el objeto de evitar la posible explicación de la aparición de metástasis cervicales contralaterales (MCC) por la localización del tumor primario en la línea media de la cavidad oral, es mandatario la inclusión selectiva de tumores que primariamente surgen en zonas laterales de la cavidad oral. De este modo es posible el análisis de las características primarias del tumor y las derivadas de su manejo quirúrgico que puedan estar asociadas con la aparición de MCC.

En nuestro conocimiento, no existen series clínicas que estudien los factores pronósticos específicos en relación con la aparición de MCC procedentes de carcinoma epidermoide de cavidad oral primariamente tratados mediante cirugía. El propósito de este estudio es determinar las características clínicas e histológicas que son factor pronóstico en la aparición de MCC en el carcinoma epidermoide de la cavidad oral.

\section{Material y método}

La presente serie está basada en 507 pacientes diagnosticados de carcinoma epidermoide de cavidad oral que fueron primariamente tratados en el Servicio de Cirugía Oral y Maxilofacial del Hospital Universitario La Princesa, Madrid, España, desde junio de 1979 a diciembre de 1999. Los pacientes fueron seleccionados a partir de una base de datos recogidos prospectivamente. Los pacientes fueron tratados con cirugía con o sin radioterapia coadyuvante. La cirugía fue realizada en todos los casos por el mismo equipo quirúrgico. Se consideró el estudio de factores relacionados con la cirugía, y por tanto fueron desestimados aquellos pacientes que recibieron tratamiento radioterápico o quimioterápico como tratamiento primario. Solo una pequeña proporción de los pacientes (menos del 2\%) de los pacientes con carcinoma epidermoide de la cavidad oral no fueron incluidos en el estudio. Estos casos fueron el resultado de enfermedad avanzada asociada a pobre estado general del paciente en el momento del diagnóstico.

Se establecieron una serie de criterios de exclusión: (1) tumores que aparecieron primariamente en línea media de la cavidad oral, (2) pacientes con cáncer oral o de cabeza y cuello múltiple (87 de 517 pacientes), (3) pacientes con recurrencia de un tumor primario previo (52 de 517 pacientes), (4) metástasis a distancia en el momento del diagnóstico, (5) contraindicación para la cirugía, por tumor irresecable o paciente inoperable. La presencia de uno solo de estos criterios fue suficiente para excluir el caso. Se seleccionaron los pacientes con tumores primariamente localizados en la zona lateral de la cavidad oral. Dentro de estos quedan incluidos el carcinoma epidermoide del borde lateral de la lengua libre, encía alveolar distal a ambos caninos, suelo de boca distal a la altura marcada por la prolongación hacia posterior de ambos caninos inferiores y mucosa yugal. No se estableció límite alguno en el estadio tumoral, incluyéndose pacientes con estadios I a IV en la clasificación TNM. Se establecieron los siguientes criterios de inclusión: (1) confirmación histológica de carcinoma epidermoide de mucosa oral, y (2) ausencia de tratamiento previo. El diagnóstico por imagen fue giva, buccal mucosa and floor of the mouth. In order to avoid the possible explication for the appearance of contralateral neck metastasis (CNM) as a result of the primary tumor site being in the midline of the oral cavity, the selective inclusion of tumors that arise primarily in lateral zones of the oral cavity is mandatory. The analysis of the primary characteristics of the tumor is in this way possible, together with those arising from surgical manipulation that can be associated with the appearance of CNM.

To our knowledge, there are no clinical series that examine specific prognostic factors with regard to the appearance of CNM from squamous cell carcinoma of the oral cavity that has been treated primarily with surgery. The aim of this study is to determine the clinical and histological characteristics that are prognostic factors in the appearance of CNM in squamous cell carcinoma of the oral cavity.

\section{Patients and methods}

This series is based on 507 patients who were diagnosed with squamous cell carcinoma of the oral cavity and who were primarily treated by the department of Oral and Maxillofacial Surgery of the Hospital Universitario La Princesa, Madrid, Spain from June 1979 to December 1999. The patients were chosen from a data base and in a prospective fashion. The patients were treated with surgery, with or without coadjuvant radiotherapy. The surgery was carried out in all cases by the same surgical team. Factors related to the surgery were taken into account, and those patients who had received radiotherapy or chemotherapy as primary treatment were not included. Only a small proportion of patients (less than 2\%) with squamous cell carcinoma of the oral cavity were not included in the study. These cases were the result of advanced disease together with the poor general health of the patient at diagnosis.

A series of exclusion criteria were established: (1) tumors that appeared primarily in the midline of the oral cavity, (2) patients with multiple oral or head and neck cancers (87 of the 517 patients), (3) patients with recurrence of a previous primary tumor (52 of 517 patients), (4) distant metastasis at diagnosis, (5) contraindication for surgery, irremovable tumor or inoperable patient. The presence of just one of these criteria was sufficient to exclude the case. Patients were chosen with tumors that were primarily located in the lateral area of the oral cavity. Within these, squamous cell carcinoma of the lateral border of the mobile tongue, alveolar gingiva distal to both canines, floor of the mouth distal to the height marked by the prolongation backwards of both lower canines and jugal mucosa were included. No limit was set for tumor stage, and patients with Stage I to IV by TNM classification were included. The following inclusion criteria were established: (1) histologic confirmation of squamous cell carcinoma of the oral mucosa, and (2) absence of previous treatment. Diagnosis by imaging was established by 
establecido mediante tomografía computerizada (TC) y/o resonancia magnética nuclear (RM). Se incluyeron un total de 315 pacientes con carcinoma epidermoide de cavidad oral y un subgrupo de 203 pacientes con carcinoma epidermoide de lengua. El estadiaje cervical se realizó mediante exploración física, TC y RM.

Las siguientes variables fueron analizadas para cada paciente: edad, sexo, hábitos tóxicos, fecha del diagnóstico, características clínicas del tumor, grado de diferenciación histológica, estadio clínico de la clasificación TNM, número y localización de las adenopatías cervicales, tipo de reconstrucción quirúrgica, disección cervical, administración de radioterapia postoperatoria, recurrencia local, regional y a distancia, y resultados de supervivencia enfermedad-específica. El estudio histológico incluyó las siguientes variables: clasificación pTNM, tamaño tumoral, márgenes quirúrgicos, infiltración perineural, inflamación peritumoral y afectación ósea.

A todos los pacientes se les practicó resección quirúrgica del tumor primario con márgenes macroscópicos (mayores de $1 \mathrm{~cm}$ ). Los tumores fueron clasificados de acuerdo con la clasificación de estadio tumoral TNM. ${ }^{7}$ Se realizaron diferentes tipos disección cervical: (1) disección cervical radical modificada tipo 3 ipsilateral en pacientes con tumores $(\mathrm{T} 2, \mathrm{~T} 3, \mathrm{~T} 4) \mathrm{N} 0$ o con tumores con adenopatías cervicales menores de $3 \mathrm{~cm}$ sin extensión extracapsular (adenopatías no adheridas); (2) disección cervical radical modificada tipo 3 bilateral cuando la invasión de la línea media de la cavidad oral estaba presente como resultado de la extensión desde la zona lateral de la cavidad oral en pacientes N0 y N1; (3) disección cervical radical clásica ipsilateral cuando estaban presentes adenopatías de tamaño igual y mayor de $3 \mathrm{~cm}$, adenopatías fijas o afectación del nervio espinal; (4) disección cervical radical clásica ipsilateral junto con disección cervical radical modificada tipo 3 contralateral en pacientes con cuello N2 o N3 ipsilateral y cuello N0 contralateral, pero con afectación de la línea media de la cavidad oral como resultado de la extensión desde la zona lateral; y (5) disección cervical radical clásica contralateral junto con disección cervical radical modificada tipo 3 ipsilateral en 1 paciente con adenopatía patológica contralateral mayor de $3 \mathrm{~cm}$ (N2) en el momento del diagnóstico. A pesar del tratamiento agresivo inicial, este último paciente presentó recidiva cervical contralateral durante el seguimiento. Se consideró como una verdadera recidiva y fue incluido en el estudio.

De acuerdo con el Servicio de Oncología Radioterápica, se administró tratamiento radioterápico coadyuvante entre 60 y 70 Gy en aquellos pacientes en quienes los márgenes quirúrgicos fueron menores de $1 \mathrm{~cm}$ en la pieza analizada. Los tumores clasificados como pT3 o mayores recibieron también tratamiento radioterápico coadyuvante. Por lo tanto, la invasión de hueso (T4) se consideró indicación de tratamiento radioterápico. Otros factores tumorales indicativos de tratamiento radioterápico complementario se consideraron tras el análisis histológico: crecimiento tumoral radial, displasia en los márgenes de resección, invasión de vasos linfáticos o sanguíneos e infiltración perineural. Se empleó asimismo radioterapia coadyuvante regional cuando se demostraron más de 3 adenopatías cervicales patológicas o extensión extracapsular. Solamente aquellos casos con afectación demostrada del cuello contralateral fueron tratados mediante radioterapia coadyuvante en el cuello contralateral tras la disección cervical. means of computerized tomography (CT) and/or nuclear magnetic resonance (NMR). A total of 315 patients were included with squamous cell carcinoma of the oral cavity and a subgroup of 203 patients with squamous cell carcinoma of the tongue.

The following variables were analyzed for each patient: age, sex, toxic habits, date of diagnosis, clinical characteristics of tumor, degree of histological differentiation, clinical stage by TNM classification, number and location of neck nodes involved, type of surgical reconstruction, neck dissection, administration of postoperative radiotherapy, local regional or distant recurrence, and results of disease-specific survival. The histologic study included the following variables: PTNM classification, tumor size, surgical margins, perineural infiltration, peritumoral inflammation and bone involvement.

All patients underwent surgical resection of the primary tumor with macroscopic margins (greater than $1 \mathrm{~cm}$ ). The tumors were classified by TNM classification regarding tumor stage.7 Different types of neck dissection were carried out: (1) Ipsilateral Type 3 modified radical neck dissection in patients with $(T 2, T 3, T 4) \mathrm{NO}$ tumors, or with tumors with neck node involvement of less than $3 \mathrm{~cm}$ without extracapsular extension (unattached nodal swelling); (2) Bilateral Type 3 modified radical neck dissection when there was invasion of the midline of the oral cavity as a result of extension from the lateral area of the oral cavity in N0 and N1 patients; (3) ipsilateral classical radical neck dissection when there was swelling of $3 \mathrm{~cm}$ or more, attached nodes or spinal nerve involvement; (4) ipsilateral classical radical neck dissection together with contralateral Type 3 modified radical neck dissection in patients with N2 or N3 ipsilateral necks and contralateral NO necks, but with midline involvement of the oral cavity as a result of extension from the lateral area; and (5) contralateral classical radical neck dissection together with ipsilateral Type 3 modified radical neck dissection in one patient with contralateral pathological swelling greater than $3 \mathrm{~cm}$ (N2) at diagnosis. In spite of initial aggressive treatment, this last patient showed contralateral neck recurrence during the follow-up. It was considered a true recurrence and it was included in the study.

In accordance with the Department of Oncological Radiotherapy, coadjuvant radiotherapy treatment was administered that was between 60 and $70 \mathrm{~Gy}$ for those patients whose specimen had margins of less than $1 \mathrm{~cm}$. Tumors that were classified as PT3 or greater, also received coadjuvant radiotherapy treatment. Regional coadjuvant radiotherapy was used when more than three pathological neck nodes or extracapsular extension were demonstrated. Only those cases with contralateral neck involvement were treated by means of coadjuvant radiotherapy of the contralateral neck after the neck dissection.

The patients were grouped together and analyzed according to the type of neck dissection carried out (Table 2). The necks were classified as positive or negative for neck metas- 
Tabla 1. Pacientes con carcinoma epidermoide de cavidad oral. Recurrencia en relación con el tipo de disección cervical

\begin{tabular}{|c|c|c|c|c|c|}
\hline & \multirow[t]{2}{*}{ No. pacientes } & \multicolumn{2}{|c|}{ pNO neck } & \multicolumn{2}{|c|}{$\mathrm{pN}+$ neck } \\
\hline & & $\begin{array}{l}\text { Tasa de recidiva } \\
\text { ipsilateral }\end{array}$ & $\begin{array}{l}\text { Tasa de recidiva } \\
\text { contralateral }\end{array}$ & $\begin{array}{l}\text { Tasa de recidiva } \\
\text { ipsilateral }\end{array}$ & $\begin{array}{c}\text { Tasa de recidiva } \\
\text { contralateral }\end{array}$ \\
\hline No disección cervical & 101 & $16 / 101$ & $2 / 101$ & $0 / 0$ & $0 / 0$ \\
\hline Ipsilateral radical modificada tipo 3 & 137 & $3 / 98$ & $8 / 98$ & $1 / 39$ & $2 / 39$ \\
\hline Bilateral radical modificada tipo 3 & 55 & $2 / 29$ & $0 / 29$ & $2 / 26$ & $1 / 26$ \\
\hline Ipsilateral radical clásica & 13 & $0 / 0$ & $0 / 0$ & $1 / 8$ & $1 / 8$ \\
\hline $\begin{array}{l}\text { Ipsilateral radical clásica + } \\
+ \text { contralateral radical modificada tipo } 3\end{array}$ & 5 & $1 / 2$ & $0 / 2$ & $0 / 3$ & $0 / 3$ \\
\hline $\begin{array}{l}\text { Ipsilateral radical modificada tipo } 3 \text { + } \\
\text { + Contralateral radical clásica }\end{array}$ & 4 & $1 / 1\left(^{*}\right)$ & $1 / 1\left(^{*}\right)$ & $0 / 3$ & $0 / 3$ \\
\hline
\end{tabular}

Table 1. Patients with squamous cell carcinoma of the oral cavity. Recurrence in relation to type of neck dissection

\begin{tabular}{|c|c|c|c|c|c|}
\hline & \multirow[t]{2}{*}{ No. patients } & \multicolumn{2}{|c|}{ pNO neck } & \multicolumn{2}{|c|}{$\mathrm{pN}+$ neck } \\
\hline & & $\begin{array}{c}\text { Rate of } \\
\text { ipsilateral } \\
\text { recurrence }\end{array}$ & $\begin{array}{c}\text { Rate of } \\
\text { contralateral } \\
\text { recurrence }\end{array}$ & $\begin{array}{c}\text { Rate of } \\
\text { ipsilateral } \\
\text { recurrence }\end{array}$ & $\begin{array}{c}\text { Rate of } \\
\text { contralateral } \\
\text { recurrence }\end{array}$ \\
\hline No neck dissection & 101 & $16 / 101$ & $2 / 101$ & $0 / 0$ & $0 / 0$ \\
\hline Ipsilateral Type 3 modified radical & 137 & $3 / 98$ & $8 / 98$ & $1 / 39$ & $2 / 39$ \\
\hline Bilateral Type 3 modified radical & 55 & $2 / 29$ & $0 / 29$ & $2 / 26$ & $1 / 26$ \\
\hline Ipsilateral classical radical & 13 & $0 / 0$ & $0 / 0$ & $1 / 8$ & $1 / 8$ \\
\hline $\begin{array}{l}\text { Ipsilateral classical radical }+ \\
+ \text { contralateral Type } 3 \text { modified radica }\end{array}$ & 5 & $1 / 2$ & $0 / 2$ & $0 / 3$ & $0 / 3$ \\
\hline $\begin{array}{l}\text { Ipsilateral Type } 3 \text { modified radical + } \\
\text { + Contralateral classical radical }\end{array}$ & 4 & $1 / 1\left(^{*}\right)$ & $1 / 1\left(^{*}\right)$ & $0 / 3$ & $0 / 3$ \\
\hline
\end{tabular}

Se recogieron y analizaron los pacientes en función del tipo de disección cervical empleada (Tabla 1). Los cuellos fueron clasificados como positivos o negativos para metástasis cervical tras su análisis histológico. Los eventos de recidiva cervical ipsilateral y contralateral fueron registrados durante el seguimiento. Se evaluaron las siguientes variables en relación con una hipotética asociación con la aparición de recurrencia cervical contralateral: edad, sexo, tiempo de evolución de la lesión hasta el diagnóstico, estadio clínico $\mathrm{T}$, estadio clínico $\mathrm{N}$, estadio patológico $\mathrm{T}$, estadio patológico $\mathrm{N}(\mathrm{pN})$, estadio tumoral, grado de diferenciación histopatológica, márgenes quirúrgicos tras la resección del tumor primario, espesor tumoral ( $<2 \mathrm{~mm}$ o $>2 \mathrm{~mm}$ ), tipo de disección cervical, infiltración perineural, afectación ósea, extensión extracapsular de metástasis por vía linfática y radioterapia postoperatoria.

El propósito del estudio es determinar aquellas características relacionadas con el tumor primario y su tratamiento que predicen la aparición de metástasis cervical contralateral a partir de carcinoma epidermoide de la zona lateral de la cavidad oral. Se empleó el soporte informático SPSS 13.0 (SPSS Inc, Chicago, IL) para el análisis de los datos. La posible asociación entre las características clínicas y patológicas del tumor primario con respecto a la aparición tasis after histological analysis. The incidences of ipsilateral and contralateral neck recurrence were registered during the follow-up. The following variables were evaluated in relation to a hypothetical association with the appearance of contralateral neck recurrence: age, sex, time the lesion had been evolving until diagnosis, clinical T stage, clinical $\mathrm{N}$ stage, pathological T stage, pathological $N(p N)$ stage, tumor stage, degree of histopathological differentiation, surgical margins after resection of primary tumor, tumor thickness $(<2 \mathrm{~mm} 0>2 \mathrm{~mm})$, type of neck dissection, perineural infiltration, bone involvement, extracapsular extension of metastasis via lymph vessels and postoperative radiotherapy.

The purpose of the study was to determine those characteristics related with the primary tumor and its treatment that can predict the appearance of contralateral neck metastasis from squamous cell carcinoma in the lateral area of the oral cavity. SPSS 6.12 (SPSS Inc, Chicago, IL) software was used for analyzing data. The possible association between clinical and pathological characteristics of the primary tumor with regard to the appearance of contralateral neck metastasis was determined by the Chi_square test for qualitative 
de metástasis cervical contralateral fue determinada por el test de $\chi^{2}$ para variables cualitativas y el test de t-Student para datos de variables cuantitativas que seguían una distribución gaussiana. Las curvas de supervivencia fueron calculadas mediante el método de Kaplan-Meier. Se consideró como diferencia estadísticamente significativa una $p<0,05$.

\section{Resultados}

Trescientos quince de un total de 517 pacientes con carcinoma epidermoide de cavidad oral cumplieron los criterios de inclusión. Doscientos tres pacientes de éstos presentaron carcinoma epidermoide de lengua libre. La tasa hombre:mujer fue 10:7 (10:3,9 para el subgrupo de pacientes con carcinoma epidermoide de lengua). La media de edad fue 59,99, con un rango etario entre los 18 y los 90 años. El tiempo medio desde la aparición de las primeras manifestaciones clínicas hasta el diagnóstico fue 3,94 meses (4 meses para el subgrupo de pacientes con carcinoma epidermoide de lengua), con una mediana de 2 meses y un rango de 0 a 84 meses. Referimos los factores clínico-patológicos y la aparición de metástasis linfáticas contralaterales en la tabla 2.

Ochenta y tres pacientes murieron debido a la enfermedad $(26,34 \%)$, mientras que 27 lo hicieron por otra enfermedad no relacionada con el carcinoma epidermoide de cavidad oral. Con respecto al subgrupo de pacientes con carcinoma epidermoide de lengua, cuarenta y siete pacientes murieron debido a la enfermedad $(23,15 \%)$, mientras que 19 lo hicieron por otra enfermedad no relacionada con la anterior. El tiempo de supervivencia medio enfermedad-específica para todo el grupo fue de $147 \pm 6$ meses (intervalo de confianza del 95\%: 134 a 159 meses). En relación al subgrupo de pacientes con carcinoma epidermoide de lengua este valor fue de $149 \pm 7$ meses ((intervalo de confianza del 95\%: 135 a 166 meses). La tasa de supervivencia enfermedad-específica al año, 2 años y 5 años fue del $85,6 \%, 75,8 \%$ y $71,8 \%$ respectivamente para la globalidad del conjunto (Figs. 1 y 2 ).

A la mayor parte de los pacientes de la serie se les realizó disección cervical $(\mathrm{n}=214(67,9 \%)): 137(43,5 \%)$ disección cervical radical modificada tipo 3 ipsilateral, $55(17,4 \%)$ disección cervical radical modificada tipo 3 bilateral, 13 (4,1\%) disección cervical radical clásica ipsilateral, 5 (1,6\%) disección cervical radical clásica ipsilateral junto con disección cervical radical modificada tipo 3 contralateral, y 4 (1,3\%) disección cervical radical modificada tipo 3 junto con disección cervical radical clásica contralateral. Con respecto al subgrupo de pacientes con carcinoma epidermoide de lengua estos fueron los datos: $(n=141(73,1 \%)): 80(40,6 \%)$ disección cervical radical modificada tipo 3 ipsilateral, $49(24,9 \%)$ disección cervical radical modificada tipo 3 bilateral, 5 (2,5\%) disección cervical radical clásica ipsilateral, 6 (3\%) disección cervical radical clásica ipsilateral junto con disección cervical radical modificada tipo 3 contralateral, y $1(0,5 \%)$ disección cervical radical modificada tipo 3 junto con disección cervical radical clásica contralateral. Las tablas 3 y 4 sintetizan los datos referentes al tipo de cirugía cervical y la aparición de metástasis cervical contralateral durante el seguimiento.

Ciento seis pacientes recibieron tratamiento radioterápico (33,7\%) variables and Student's T- test was used for the quantitative variables data following a Gaussian distribution. Survival curves were calculated using the Kaplan-Meier method. A $p<0.05$ difference was considered statistically significant.

\section{Results}

Of a total of 517 patients with squamous cell carcinoma of the oral cavity, 315 met the inclusion criteria. Of these, 203 had squamous cell carcinoma of the mobile tongue. The male/female rate was 10:7 (10:3.9 for the subgroup of patients with squamous cell carcinoma of the tongue). The mean age was 59.99 with ages ranging between 18 and 90. The mean time from the onset of the first clinical signs until diagnosis was 3.94 months (4 months for the subgroup of patients with squamous cell carcinoma of the tongue) with a mean of two months and a range of 0 to 84 months. The clinicopathological factors and the appearance of contralateral lymphatic metastasis appear in table 1.

Eighty-three patients died as a result of the disease (26.34\%), while 27 died because of another disease that was not related to squamous cell carcinoma of the oral cavity. With regard to the subgroup of patients with squamous cell carcinoma of the tongue, 47 patients died as a result of the disease (23.15\%), while 19 did so because of another disease not related to the first. Mean disease-specific survival time for the whole group was 147 6 months (confidence interval 95\%: 134 to 159 months). With regard to the subgroup of patients with squamous cell carcinoma of the tongue this value was $149 \pm 7$ months ((confidence interval of 95\%: 135 to 166 months). The rate of disease-specific survival at 1 year, 2 years and 5 years was $85.6 \%, 75.8 \%$ y $71.8 \%$ respectively for all groups together (Figs. 1 and 2).

Most patients in the series underwent neck dissection $(n=214$ (67.9\%)): 137 (43.5\%) ipsilateral Type 3 modified radical neck dissection, 55 (17.4\%) bilateral Type 3 modified radical neck dissection, 13 (4.1\%) ipsilateral classical radical neck dissection, 5 (1.6\%) ipsilateral classical radical neck dissection together with contralateral Type 3 modified radical neck dissection, and 4 (1.3\%) Type 3 modified radical neck dissection with contralateral classical radical neck dissection. With regard to the subgroup of patients with squamous cell carcinoma of the tongue, the data were as follows: ( $n=141$ (73.1\%)): 80 (40.6\%) ipsilateral Type 3 modified radical neck dissection, 49 (24.9\%) bilateral Type 3 modified radical neck dissection, 5 (2.5\%) ipsilateral classical radical neck dissection, 6 (3\%) ipsilateral classical radical neck dissection together with contralateral Type 3 modified radical neck dissection, and 1 (0.5\%) Type 3 modified radical neck dissection together with contralateral classical radical neck dissection. Tables 3 and 4 synthesize the data referring to the type of neck surgery and the appearance of contralateral neck metastasis during the follow-up period. 
Tabla 2. Distribución de factores clínico-patológicos y aparición de metástasis cervical contralateral

\begin{tabular}{|c|c|c|}
\hline & Pacientes (\%) & $\begin{array}{l}\text { Pacientes con metástasis } \\
\text { cervical contralateral (\%) }\end{array}$ \\
\hline \multicolumn{3}{|l|}{ Sexo } \\
\hline Hombre & $222(70,4)$ & $13(4.1)$ \\
\hline Mujer & $93(29,8)$ & $5(1,5)$ \\
\hline \multicolumn{3}{|l|}{$\mathrm{T}$} \\
\hline Tis & $6(1,9)$ & $0(0)$ \\
\hline T1 & $73(23,1)$ & $3(0,9)$ \\
\hline $\mathrm{T} 2$ & $122(38,6)$ & $9(2,8)$ \\
\hline T3 & $37(11,7)$ & $1(0,3)$ \\
\hline $\mathrm{T} 4$ & $76(24,1)$ & $5(1,5)$ \\
\hline \multicolumn{3}{|l|}{$\mathrm{N}$} \\
\hline No & $230(73,0)$ & $14(4,4)$ \\
\hline N1 (adenopatía ipsilateral $\leq 3 \mathrm{~cm}$ ) & $53(16,8)$ & $3(0,9)$ \\
\hline N2a (adenopatía ipsilateral 3-6 cm) & $7(2,2)$ & $0(0)$ \\
\hline N2b (adenopatías ipsilateral múltiples $<6 \mathrm{~cm}$ ) & $10(3,2)$ & $1(0,3)$ \\
\hline N2c (bilateral o contralateral) & $8(2,5)$ & $0(0)$ \\
\hline N3 (multiples, una al menos $>6 \mathrm{~cm}$ ) & $3(0,9)$ & $0(0)$ \\
\hline \multicolumn{3}{|l|}{ Disección cervical } \\
\hline No & $94(29,8)$ & $2(0,6)$ \\
\hline Ipsilateral radical modificada tipo 3 & $137(43,5)$ & $13(4,1)$ \\
\hline Bilateral radical modificada tipo 3 & $55(17,4)$ & $1(0)$ \\
\hline Ipsilateral radical clásica & $13(4,1)$ & $1(0.3)$ \\
\hline Ipsilateral radical clásica + & & \\
\hline $\begin{array}{l}\text { + Contralateral radical modificada tipo } 3 \\
\text { Ipsilateral radical clásica + }\end{array}$ & $5(1,6)$ & $0(0)$ \\
\hline + Ipsilateral radical modificada tipo 3 & $4(1,3)$ & $1(0,3)$ \\
\hline \multicolumn{3}{|l|}{ Grado diferenciación histológico } \\
\hline Bien diferenciado & $135(42,8)$ & $7(2,2)$ \\
\hline Moderadamente diferenciado & $139(44,1)$ & $7(2,2)$ \\
\hline Pobremente diferenciado & $37(11,7)$ & $4(1,2)$ \\
\hline Ausencia de datos & 1 & \\
\hline \multicolumn{3}{|l|}{ pT } \\
\hline pT0 & $12(3,8)$ & $0(0)$ \\
\hline pT1 & $93(29,5)$ & $4(1,2)$ \\
\hline рT2 & $100(31,7)$ & $6(1,9)$ \\
\hline pT3 & $31(9,8)$ & $2(0,6)$ \\
\hline pT4 & $64(20,3)$ & $6(1,9)$ \\
\hline Ausencia de datos & 15 & \\
\hline \multicolumn{3}{|l|}{ Márgenes quirúrgicos } \\
\hline Correctos $(\geq 1 \mathrm{~cm})$ & $222(70,5)$ & $9(2,8)$ \\
\hline Afectación microscópica & $46(14,6)$ & $4(1,2)$ \\
\hline Afectación macroscópica & $3(1,0)$ & $0(0)$ \\
\hline Libre insuficiente $(<1 \mathrm{~cm})$ & $28(8.9)$ & $4(1,2)$ \\
\hline Ausencia de datos & 16 & 1) \\
\hline \multicolumn{3}{|l|}{ Espesor tumoral } \\
\hline$<2 \mathrm{~mm}$ & $35(11,1)$ & $0(0)$ \\
\hline$>2 \mathrm{~mm}$ & $226(71,5)$ & $18(5,7)$ \\
\hline Ausencia de datos & 54 & \\
\hline \multicolumn{3}{|l|}{ Inflamación peritumoral } \\
\hline No & $180(57,3)$ & $12(3,8)$ \\
\hline Escasa & $54(17,2)$ & $0(0)$ \\
\hline Moderada & $54(17,2)$ & $2(0,6)$ \\
\hline Intensa & $26(8.3)$ & $4(1,2)$ \\
\hline (Ausencia de datos & 1) & \\
\hline \multicolumn{3}{|l|}{ Infiltración perineural } \\
\hline Sí & $48(15,2)$ & $8(2,5)$ \\
\hline No & $167(84,8)$ & $6(1,9)$ \\
\hline Ausencia de datos & 100 & 4 \\
\hline \multicolumn{3}{|l|}{ Afectación ósea } \\
\hline Sí & $45(14,3)$ & $3(0,9)$ \\
\hline No & $270(85,7)$ & $15(4,7)$ \\
\hline
\end{tabular}


Table 2. Distribution of clinicopathological factors and appearance of contralateral neck metastasis

\section{Patients (\%)}

Sex

Male

Female

$T$

Tis

T1

$T 2$

T3

T4

N

NO

N1 (ipsilateral adenopathy $\leq 3 \mathrm{~cm}$ )

$\mathrm{N} 2 a$ (ipsilateral adenopathy 3-6 cm)

$\mathrm{N} 2 b$ (multiple ipsilateral adenopathy $<6 \mathrm{~cm}$ )

$\mathrm{N} 2 \mathrm{c}$ (bilateral or contralateral)

N3 (multiple, with one at least $>6 \mathrm{~cm}$ )

Neck dissection

No

Ipsilateral Type 3 modified radical

Bilateral Type 3 modified radical

Ipsilateral classical radical

Ipsilateral classical radical +

+ Contralateral Type 3 modified radical

Ipsilateral classical radical +

+ Ipsilateral Type 3 modified radical

Histological differentiation grade

Well differentiated

Moderately differentiated

Poorly differentiated

Absence of data

pT

pTO

pT1

pT2

pT3

pT4

(Absence of data

Surgical margins

Correct ( $\geq 1 \mathrm{~cm}$ )

Microscopic involvement

Macroscopic involvement

Insufficient free margin $(<1 \mathrm{~cm})$

Absence of data

Tumor thickness

$<2 \mathrm{~mm}$

$>2 \mathrm{~mm}$

Absence of data

Peritumoral inflammation

None

Scarce

Moderate

Intense

Absence of data

Perineural infiltration

Yes

No

Absence of data

Bone involvement

Yes

No
$222(70,4)$

$93(29,8)$

$6(1,9)$

$73(23,1)$

$122(38,6)$

$37(11,7)$

$76(24,1)$

$230(73.0)$

$53(16.8)$

7 (2.2)

$10(3.2)$

8 (2.5)

$3(0.9)$

94 (29.8)

$137(43.5)$

$55(17.4)$

$13(4.1)$

$5(1.6)$

4 (1.3)

135 (42.8)

$37(11.7)$

1

$12(3.8)$

93 (29.5)

$100(31.7)$

31 (9.8)

$64(20.3)$

15)

$222(70.5)$

$46(14.6)$

$3(1.0)$

28 (8.9)

16

35 (11.1)

226 (71.5)

54

$180(57.3)$

$54(17.2)$

$54(17.2)$

$26(8.3)$

48 (15.2)

$167(84.8)$

100

$45(14.3)$

$270(85.7)$
$139(44.1)$
Patients with contralateral neck metastasis (\%)

$13(4.1)$

$5(1,5)$

$0(0)$

$3(0,9)$

$9(2,8)$

$1(0,3)$

$5(1,5)$

$14(4.4)$

$3(0.9)$

$0(0)$

$1(0.3)$

$0(0)$

$0(0)$

$2(0.6)$

$13(4.1)$

$1(0)$

$1(0.3)$

$0(0)$

$1(0.3)$

7 (2.2)

$7(2.2)$

$4(1.2)$

$0(0)$

$4(1.2)$

$6(1.9)$

$2(0.6)$

$6(1.9)$

$9(2.8)$

$4(1.2)$

$0(0)$

$4(1.2)$

1

$0(0)$

$18(5.7)$

12 (3.8)

$0(0)$

$2(0.6)$

4 (1.2)

8 (2.5)

$6(1.9)$

4

$3(0.9)$

$15(4.7)$ 
después de la cirugía. En los pacientes con carcinoma epidermoide de lengua esta cifra ascendió a $73(37,6 \%)$. Sesenta y cuatro $(20,3 \%)$ desarrollaron recurrencia local después del tratamiento definitivo. Veintinueve pacientes desarrollaron recurrencia cervical ipsilateral $(9,1 \%)$ mientras que $18(5,7 \%)$ presentaron metástasis cervical contralateral. La frecuencia de aparición de recidiva local y regional simultáneamente fue del $6,3 \%$ y la de metástasis a distancia 7,9\%. Para los pacientes con carcinoma epidermoide de lengua estas últimas cifras fueron de $9,8 \%$ y $7,4 \%$ respectivamente. Para la serie global, 18 de 29 pacientes con recidiva cervical ipsilateral finalmente murieron de la enfermedad. Siete de los 18 pacientes con recidiva cervical contralateral murieron igualmente de la enfermedad. El período medio desde la cirugía a la aparición de las MCC fue de 12,52 meses (rango, de 3 a 49 meses). La mayoría de los pacientes $(72,2 \%)$ que presentaron MCC habían sido manejados inicialmente mediante una disección cervical radical modificada de tipo 3. Uno de estos casos recibió además disección cervical radical clásica contralateral. Se debió a la ausencia de adenopatías cervicales ipsilaterales pero la presencia de MCC al diagnóstico. Dos pacientes no recibieron disección cervical primariamente y fueron sometidos a disección cervical radical modificada tipo 3 cuando finalmente apareció la MCC. En resumen, diez de los 18 pacientes con MCC fueron candidatos a cirugía de disección cervical posterior. Los restantes 8 pacientes no fueron candidatos a cirugía y solamente se ofreció tratamiento paliativo o radioterapia. Al final del periodo de seguimiento, solamente 7 de los 18 pacientes permanecía vivo sin evidencia de enfermedad (Tabla 5).

En relación con los factores clínicopatológicos analizados se observó asociación estadísticamente significativa con $p<0,05$ con respecto a la aparición de metástasis cervical contralateral para: tiempo en meses hasta el diagnóstico, estadio tumoral de la clasificación TNM, estado N clínico ipsilateral, grado de diferenciación histopatológica, márgenes quirúrgicos en la resección del tumor primario, tipo de disección cervical e infiltración perineural. De este modo se demostraron como factores predictivos de metástasis cervical contralateral la demora de 12 meses o más en el diagnóstico $(p=0,03)$, el estadio tumoral IV de la clasificación TNM $(p=0,03)$, la presencia de $\mathrm{N}$ positivo ipsilateral en el momento del diagnóstico
One hundred and six patients received radiotherapy treatment (33.7\%) after surgery. Of the patients with squamous cell carcinoma of the tongue this figure rose to 73 (37.6\%). Sixty-four (20.3\%) developed local recurrence after definitive treatment. Twenty-nine patients developed ipsilateral neck recurrence (9.1\%) while 18 (5.7\%) had contralateral neck metastasis. The frequency with which local and regional recurrence appeared simultaneously was $6.3 \%$ and metastasis at a distance was 7.9\%. For those patients with squamous cell carcinoma of the tongue this last figure was $9.8 \%$ and $7.4 \%$ respectively. For the global series, 18 out of 29 patients with ipsilateral neck recurrence finally died of the disease. Seven of the 18 patients with contralateral neck recurrence also died of the disease. The mean period between surgery and the appearance of CNM was 12.52 months (with a range of 3 to 49 months). Most patients (72.2\%) that presented with CNM had been managed initially with a Type 3 modified radical neck dissection. One of these cases received in addition a contralateral classical radical neck dissection. This was due to the absence of ipsilateral neck involvement but the presence of CNM at diagnosis. Two patients did not receive neck dissection primarily and they underwent a Type 3 modified radical neck dissection when CNM finally appeared. To sum up, ten out of the 18 patients with CNM were candidates for later neck dissection. The remaining eight were not candidates for surgery and they were only given palliative or radiotherapy treatment. At the end of the follow-up period only seven of the 18 patients remained alive with no evidence of the disease (Table 5).

With regard to the clinicopathological factors analyzed, a statistically significant association was observed with regard to $p<0.05$ in relation to the appearance of contralateral neck metastasis for: time in terms of months until 
Tabla 3. Pacientes con carcinoma epidermoide de lengua. Recurrencia en relación con el tipo de disección cervical

\begin{tabular}{|c|c|c|c|c|c|}
\hline & \multirow[t]{2}{*}{ No. pacientes } & \multicolumn{2}{|c|}{ pNO neck } & \multicolumn{2}{|c|}{ pN+ neck } \\
\hline & & $\begin{array}{l}\text { Tasa de recidiva } \\
\text { ipsilateral }\end{array}$ & $\begin{array}{c}\text { Tasa de recidiva } \\
\text { contralateral }\end{array}$ & $\begin{array}{l}\text { Tasa de recidiva } \\
\text { ipsilateral }\end{array}$ & $\begin{array}{c}\text { Tasa de recidiva } \\
\text { contralateral }\end{array}$ \\
\hline Bilateral radical modificada tipo 3 & 49 & $1 / 25$ & $0 / 25$ & $3 / 24$ & $0 / 24$ \\
\hline Ipsilateral radical clásica & 5 & $0 / 0$ & $0 / 0$ & $1 / 5$ & $0 / 5$ \\
\hline $\begin{array}{l}\text { Ipsilateral radical clásica + } \\
\text { + contralateral radical modificada tipo } 3\end{array}$ & 6 & $1 / 1$ & $0 / 1$ & $1 / 5$ & $0 / 5$ \\
\hline
\end{tabular}

Table 3. Patients with squamous cell carcinoma of the tongue. Recurrence in relation to type of neck dissection

\begin{tabular}{|c|c|c|c|c|c|}
\hline & \multirow[t]{2}{*}{ No. pacientes } & \multicolumn{2}{|c|}{ pNO neck } & \multicolumn{2}{|c|}{$p N+n e c k$} \\
\hline & & $\begin{array}{l}\text { Rate of } \\
\text { ipsilateral } \\
\text { recurrence }\end{array}$ & $\begin{array}{l}\text { Rate of } \\
\text { contralateral } \\
\text { recurrence }\end{array}$ & $\begin{array}{l}\text { Rate of } \\
\text { ipsilateral } \\
\text { recurrence }\end{array}$ & $\begin{array}{l}\text { Rate of } \\
\text { contralateral } \\
\text { recurrence }\end{array}$ \\
\hline Ipsilateral Type 3 modified radical & 80 & $2 / 58$ & $4 / 58$ & $0 / 22$ & $3 / 22$ \\
\hline Bilateral Type 3 modified radical & 49 & $1 / 25$ & $0 / 25$ & $3 / 24$ & $0 / 24$ \\
\hline Ipsilateral classical radical & 5 & $0 / 0$ & $0 / 0$ & $1 / 5$ & $0 / 5$ \\
\hline $\begin{array}{l}\text { Ipsilateral classical radical + } \\
+ \text { contralateral Type } 3 \text { modified radical }\end{array}$ & 6 & $1 / 1$ & $0 / 1$ & $1 / 5$ & $0 / 5$ \\
\hline $\begin{array}{l}\text { Ipsilateral Type } 3 \text { modified radical + } \\
+ \text { Contralateral classical radical }\end{array}$ & 1 & $0 / 0$ & $0 / 0$ & $1 / 1$ & $1 / 1$ * \\
\hline
\end{tabular}

$(p=0,04)$, la pobre diferenciación histopatológica del tumor primario $(p=0,04)$, la presencia de márgenes quirúrgicos menores de $1 \mathrm{~cm}$ en la pieza de resección del tumor primario $(p=0,007)$, la realización de disección cervical funcional ipsilateral de modo aislado $(p=0,04)$ y la afectación perineural $(p=0,0002)$. En el subgrupo de pacientes con carcinoma epidermoide de lengua libre, ni el estado $\mathrm{N}$ clínico ipsilateral $(\mathrm{N})$ ni el estadio $\mathrm{N}$ patológico ipsilateral $(\mathrm{pN})$ mostraron asociación estadísticamente significativa con la aparición de MCC, aunque sí lo hicieron el grado histológico pobremente diferenciado del tumor primario y la ausencia de inflamación peritumoral.

\section{Discusión}

La recurrencia local y la recidiva linfática cervical afectan el pronóstico y disminuyen la supervivencia de los pacientes con carcinoma epidermoide de cavidad oral. ${ }^{1-3}$ Es conocido el devenir desafortunado de los pacientes que desarrollan metástasis cervical contralateral. Diversos autores han analizado los diferentes factores relacionados con un riesgo aumentado de desarrollar metástasis cervical contralateral en tumores de cavidad oral, aunque no existen series clínicas largas.

En relación con el carcinoma epidermoide de la cavidad oral, se han referido frecuencias de metástasis cervical contralateral comprendidas entre 0,9\% y 34,7\%.4,6 Kowalski y cols. ${ }^{7}$ refirieron una diagnosis, tumor stage by TNM classification, ipsilateral clinical N stage, degree of histopathological differentiation, surgical margins of the primary tumor resection, type of neck dissection and perineural infiltration. In this sense predictive factors for contralateral neck metastasis appeared to be a delay of 12 months or more in the diagnosis $(p=0.03)$, tumor stage IV by TNM classification ( $p=0.03)$, the presence of ipsilateral positive $N$ at diagnosis $(p=0.04)$, the poor histopathologic differentiation of the primary tumor $(p=0.04)$, the presence of surgical margins of less than $1 \mathrm{~cm}$ of the resected specimen of the primary tumor ( $p=0.007)$, carrying out ipsilateral functional neck dissection in an isolated fashion $(p=0.04)$, perineural involvement $(p=0.0002)$. In the subgroup of patients with squamous cell carcinoma of the mobile tongue, only ipsilateral clinical $N$ stage showed an association that was statistically significant, to the extent that the presence of ipsilateral pathological lymph nodes in the neck at diagnosis was seen as a predictive factor for contralateral neck recurrence.

\section{Discussion}

Local recurrence and recurrence in the lymphatic system of the neck affect prognosis and reduces survival for patients with squamous cell carcinoma of the oral cavity.1,2,3 The 
incidencia del 14\% para metástasis cervical contralateral, en consonancia con los datos publicados por Kurita y cols. ${ }^{8}$ Nuestros resultados $(5,7 \%)$ se encuentran por debajo de estas cifras. Es conocida la influencia de ciertos factores del tumor primario en la aparición de metástasis cervical contralateral, como la localización del mismo en la línea media. Se han referido frecuencias aumentadas de recurrencia cervical contralateral para aquellos pacientes con tumores de la región anterior del suelo de la boca y tercio anterior de la lengua. Sin embargo, la existencia de datos bien contrastados acerca de la mayor incidencia de metástasis cervical contralateral en pacientes con carcinoma epidermoide de encía inferior (25\%) en comparación con aquellos tumores primariamente localizados en lengua libre $(15,4 \%)$ hace necesario un mayor número de series clínicas para determinar el grado de influencia de la localización tumoral.

Considerando la localización del tumor primario, la importancia de la invasión de la línea media ha sido enfatizada por Martin y cols. ${ }^{4}$ En su serie, $16 \%$ de los pacientes con tumores que cruzaban la línea media menos de $1 \mathrm{~cm}$ desarrollaron metástasis cervical contralateral. Este valor se incrementó a $46 \%$ en los casos en los que la invasión de la línea media superaba el centímetro. Todos los casos de la serie presentada por nuestro grupo afectaban primariamente la cavidad oral en su parte lateral, descartándose expresamente todos aquellos tumores que se situaban en la zona comprendida entre ambos caninos. Esta selección se realizó en un intento de obviar la influencia de la localización del tumor primario en el desarrollo ulterior de MCC. Incidiendo en este aspecto, Kurita y cols, ${ }^{8}$ encontraron asociación estadísticamente significativa entre la extensión tumoral radiológica más allá de la línea media y la aparición de MCC. Sin embargo, el análisis multivariante demuestra que este no es el único factor destacable y que otros factores deben ser considerados globalmente. ${ }^{3}$
Pacientes (\%) Pacientes con metástasis cervical contralateral (\%)

$\begin{array}{rc}64(20,3) & 5(1,5) \\ 29(9,2) & 4(1,2) \\ 18(5,7) & 18(5,7) \\ 20(6,3) & 0(0) \\ 25(7,9) & 1(0,3) \\ & \\ 177(56,1) & 7(2,1) \\ 6(1,9) & 2(0,6) \\ 83(26,3) & 7(2,1) \\ 27(8,5) & 1(0,3) \\ 32 & 1\end{array}$

unfortunate outcome of patients who develop contralateral neck metastasis is well-known various authors have analyzed the different factors related to a high risk of developing contralateral neck metastasis in tumors of the oral c a vity. although there are no lengthy clinical series.

With regard to squamous cell carcinoma of the oral cavity, recurrence of contralateral neck metastasis has been reported between 0.9\% y $34.7 \% .4,6$ Kowalski et al.7 reported an incidence of $14 \%$ for contralateral neck metastasis in consonance with the data published by Kurita et al. 8 Our results (5.7\%) were below these figures. The influence of certain factors in the primary tumor and the appearance of contralateral neck metastasis, such as a midline location are well-known. Increased rates of contralateral neck recurrence for those patients with tumors in the anterior region of the floor of the mouth and anterior third of the tongue. However, the existence of properly contrasted data on the greater incidence of contralateral neck metastasis in patients with squamous cell carcinoma of the lower gingiva (25\%) compared with those tumors that were primarily located in the mobile tongue (15.4) makes a greater number of clinical series necessary in order to determine the degree of influence of tumor location.

Considering the location of the primary tumor, the importance of invasion of the midline has been emphasized by Martin et al. 4 In their series, $16 \%$ of patients with tumors crossing the midline by less than $1 \mathrm{~cm}$ developed contralateral neck metastasis. This value increased to $46 \%$ in cases when invasion of the midline was over a centimeter. All cases 
Tabla 5. Resumen de pacientes con carcinoma epidermoide de cavidad oral que desarrollaron metástasis cervical contralateral

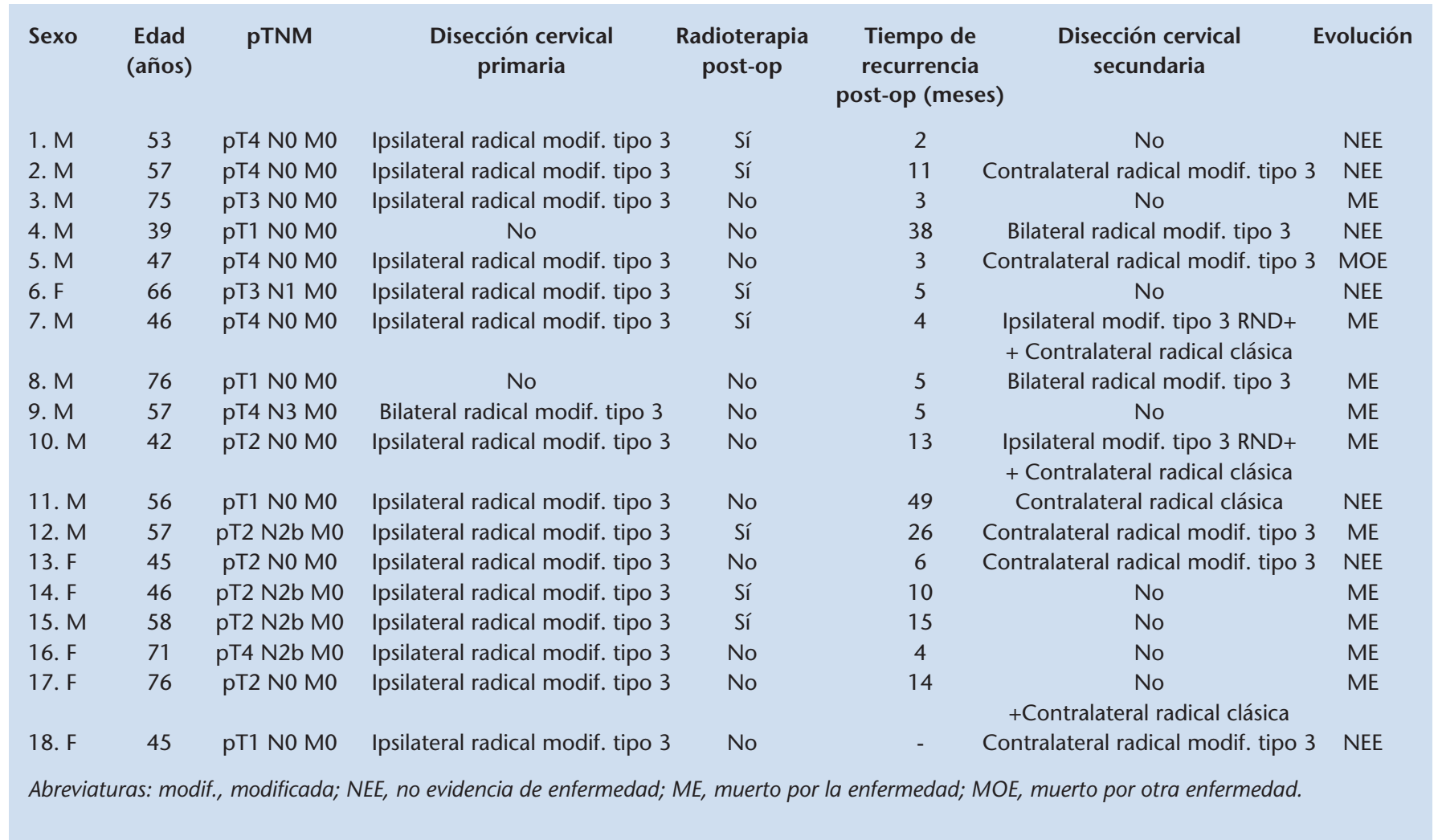

Table 5. Summary of patients with squamous cell carcinoma of the oral cavity that developed contralateral neck metastasis

\begin{tabular}{|c|c|c|c|c|c|c|c|}
\hline Sex & $\begin{array}{c}\text { Age } \\
\text { (years) }\end{array}$ & pTNM & $\begin{array}{c}\text { Primary neck } \\
\text { dissection }\end{array}$ & $\begin{array}{c}\text { Radiotherapy } \\
\text { post-op }\end{array}$ & $\begin{array}{c}\text { Time of } \\
\text { recurrence } \\
\text { post-op (months) }\end{array}$ & $\begin{array}{l}\text { Secondary neck } \\
\text { dissection }\end{array}$ & Evolution \\
\hline 1. $M$ & 53 & pT4 NO MO & Ipsilateral Type 3 mod. radical & Yes & 2 & No & NED \\
\hline 2. $M$ & 57 & pT4 NO MO & Ipsilateral Type 3 mod. radical & Yes & 11 & Contralateral Type 3 mod. radical & NED \\
\hline 3. $M$ & 75 & pT3 NO MO & Ipsilateral Type 3 mod. radical & No & 3 & No & $D D$ \\
\hline 4. $M$ & 39 & pT1 NO MO & No & No & 38 & Bilateral Type 3 mod. radical. & NED \\
\hline 5. $M$ & 47 & pT4 NO MO & Ipsilateral Type 3 mod. radical & No & 3 & Contralateral Type 3 mod. radical & $D A D$ \\
\hline 6. $F$ & 66 & pT3 N1 MO & Ipsilateral Type 3 mod. radical & Yes & 5 & No & NED \\
\hline 7. $M$ & 46 & pT4 NO MO & Ipsilateral Type 3 mod. radical & Yes & 4 & $\begin{array}{l}\text { Ipsilateral Type } 3 \text { mod. RND+ } \\
+ \text { Contralateral classical radical }\end{array}$ & $D D$ \\
\hline 8. $M$ & 76 & pT1 NO MO & No & No & 5 & Bilateral Type 3 mod. radical & $D D$ \\
\hline 9. $M$ & 57 & pT4 N3 MO & Bilateral Type 3 mod. radical & No & 5 & No & $D D$ \\
\hline 10. $M$ & 42 & pT2 NO MO & Ipsilateral Type 3 mod. radical & No & 13 & $\begin{array}{l}\text { Ipsilateral Type } 3 \text { mod. RND+ } \\
+ \text { Contralateral classical radical }\end{array}$ & $D D$ \\
\hline 11. $M$ & 56 & pT1 NOMO & Ipsilateral Type 3 mod. radical & No & 49 & Contralateral classical radical & NED \\
\hline 12. $M$ & 57 & $p T 2 N 2 b M 0$ & Ipsilateral Type 3 mod. radical & Yes & 26 & Contralateral Type 3 mod. radical & $D D$ \\
\hline 13. $F$ & 45 & pT2 NO MO & Ipsilateral Type 3 mod. radical & No & 6 & Contralateral Type 3 mod. radical & NED \\
\hline 14. $F$ & 46 & $p T 2 N 2 b M 0$ & Ipsilateral Type 3 mod. radical & Yes & 10 & No & $D D$ \\
\hline 15. $M$ & 58 & $p T 2 N 2 b M 0$ & Ipsilateral Type 3 mod. radical & Yes & 15 & No & $D D$ \\
\hline 16. $F$ & 71 & $p T 4$ N2b MO & Ipsilateral Type 3 mod. radical & No & 4 & No & $D D$ \\
\hline 17. $F$ & 76 & pT2 NO MO & Ipsilateral Type 3 mod. radical & No & 14 & $\begin{array}{c}\text { No } \\
\text { +Contralateral classical radical }\end{array}$ & $D D$ \\
\hline 18. $F$ & 45 & pT1 NO MO & Ipsilateral Type 3 mod. radical & No & - & Contralateral Type 3 mod. radical & NED \\
\hline
\end{tabular}

Abbreviations: mod., modified; NED, no evidence of disease; $D D$, dead because of disease; $D A D$, dead as a result of another disease. 
El estadio clínico de la clasificación TNM y el tamaño tumoral podrían considerarse factores pronósticos importantes en la aparición de MCC. En relación con el carcinoma epidermoide de cavidad oral, el estadio tumoral de la clasificación TNM fue predictivo de recidiva cervical contralateral en nuestra serie, aunque no pudimos demostrar asociación estadísticamente significativa con respecto al tamaño tumoral. Un 6,7\% de los pacientes con estadio clínico IV de la clasificación TNM desarrolló MCC, frente al 2,6\% de los pacientes con estadio tumoral I. De otro lado, no encontramos asociación estadísticamente significativa entre los estadios tempranos (T1-2) y la recurrencia cervical contralateral en el subgrupo de pacientes con carcinoma epidermoide de lengua. Otros autores han obtenido resultados similares. 7,8

Se consideró la posibilidad de la influencia del espesor tumoral en la aparición de recurrencia cervical contralateral. En este sentido, no hallamos asociación estadísticamente significativa entre el espesor tumoral mayor de $2 \mathrm{~mm}$ y la aparición de MCC $(p=0,06)$. Esta situación puede ser explicable por un número insuficiente de pacientes, ya que $7,1 \%$ de los pacientes con espesor tumoral mayor de $2 \mathrm{~mm}$ desarrollaron MCC, en comparación con la ausencia de casos de metástasis cervical contralateral en pacientes con tumores menores de $2 \mathrm{~mm}$ de espesor. La infiltración perineural, por el contrario, resultó fuertemente predictiva de MCC, en concreto 17,02\% de los pacientes con infiltración perineural desarrollaron metástasis, frente a únicamente el $4,1 \%$ de los que no la presentaron. De otro lado, la presencia de márgenes quirúrgicos menores de $1 \mathrm{~cm}$ en el estudio histológico se asoció con la aparición de MCC de modo estadísticamente significativo. Solo un $4 \%$ de los pacientes con márgenes de resección iguales o mayores de $1 \mathrm{~cm}$ en el estudio histológico desarrollaron MCC, frente al $11,6 \%$ de los pacientes que experimentaron resecciones con márgenes quirúrgicos menores de $1 \mathrm{~cm}$ en el estudio histológico.

El grado histológico del tumor primario y el número de adenopatías cervicales metastáticas ha sido referido como predictivo de recurrencia cervical contralateral. Demostramos que el grado histológico tumoral es factor pronóstico de MCC. De hecho, un $13,5 \%$ de los pacientes con carcinoma epidermoide pobremente diferenciado desarrolló recurrencia cervical contralateral, frente al $5,2 \%$ de los pacientes con carcinoma epidermoide bien diferenciado. Con respecto a la afectación ganglionar cervical, la presencia de adenopatías cervicales ipsilaterales positivas ha sido referida como un importante factor predictivo de la aparición de MCC en el carcinoma epidermoide de la cavidad oral.4,6,9 Es más, la aparición de MCC ha sido descrita mayoritariamente en el contexto de metástasis cervical ipsilateral $(\mathrm{MCl})$ simultánea. En relación con el carcinoma epidermoide de cavidad oral, Chow et al, 10 en una serie de 72 pacientes, demostraron una incidencia similar entre la aparición de $\mathrm{MCl}(n=7)$ y $\mathrm{MCC}(n=5)$. Nuestros resultados no suscriben estos hallazgos, pues en nuestra serie la frecuencia de MCC $(5,7 \%, \mathrm{n}=18)$ fue casi la mitad que la tasa de $\mathrm{MCl}(9,1 \%, \mathrm{n}=29)$. Demostramos la presencia de $\mathrm{MCl}$ al diagnóstico como factor pronóstico de aparición de MCC. Aunque no lo analizamos en nuestra serie, sería interesante realizar estudios histopatológicos en la región cervical que evaluaran la existencia de un patrón de diseminación desde el cuello ipsilateral al contralateral. in the series presented by our group affected primarily the lateral part of the oral cavity, and all those tumors that were situated in the area between both canines were expressly ruled out. This selection was carried out in an attempt to obviate the influence of primary tumor location in the subsequent development of CNM. With regard to this aspect, Kurita et al, 8 found an association that was statistically significant between radiologically observed tumor extension that was over the midline, and the appearance of CNM. However, multivariate analysis shows that this is not the only factor that stands out and that other factors should be taken into account globally. ${ }^{3}$

Clinical stage by TNM classification and tumor size could be considered important prognostic factors in the appearance of CNM. With regard to squamous cell carcinoma of the oral cavity, tumor stage by TNM classification was predictive of contralateral neck recurrence in our series, although we could not demonstrate an association that was statistically significant with regard to tumor size. $6.7 \%$ of patients with clinical stage IV by TNM classification developed CNM, as opposed to $2.6 \%$ of patients with a stage I tumor. Also, we did not find a statistically significant association between earlier stages (T1-2) and contralateral neck recurrence in the subgroup of patients with squamous cell carcinoma of the tongue. Other authors have obtained similar results. 7,8

The possibility of tumor thickness being influential in the appearance of contralateral neck recurrence was considered. In this sense, we did not find any association that was statistically significant between tumor thickness greater than $2 \mathrm{~mm}$ and the appearance of $\mathrm{CNM}(\mathrm{p}=0.06)$. This situation can be explained by an insufficient number of patients, as $7.1 \%$ of patients with a tumor thickness greater than $2 \mathrm{~mm}$ developed CNM, compared with an absence of cases of contralateral neck metastasis in patients with tumors of a thickness of less than $2 \mathrm{~mm}$. Perineural infiltration, on the other hand, was strongly predictive of CNM. Precisely $17.02 \%$ of patients with perineural infiltration developed metastasis, as opposed to just $4.1 \%$ of those that did not have it. On the other hand, surgical margins of less than $1 \mathrm{~cm}$ in the histological study were associated with the development of CNM, in a statistically significant fashion. Only $4 \%$ of patients with resection margins that were equal to or larger than $1 \mathrm{~cm}$ in the histological study developed CNM, as opposed to $11.6 \%$ of patients who underwent a resection with margins of less than $1 \mathrm{~cm}$ in the histological study.

The histological grade of the primary tumor and the number of metastatic neck nodes has been reported as predictive of contralateral neck recurrence. We have been able to demonstrate that the histologic grade of the tumor is a prognostic factor of CNM. In fact $13.5 \%$ of patients with poorly-differentiated squamous cell carcinoma developed contralateral neck recurrence, as opposed to $5.2 \%$ of patients with well-differentiated squamous cell carcinoma. With regard to neck lymph node involvement, the presence of positive ipsilateral neck nodes has been reported as an important 
El diagnóstico precoz es fundamental en aras de disminuir la tasa de recurrencia cervical contralateral. En nuestra serie, 23,8\% de los pacientes que fueron diagnosticados con un lapso de 12 o más meses desde la aparición de la lesión primaria presentaron MCC, en comparación con el $2,4 \%$ de los pacientes que fueron diagnosticados con menos de 12 meses de evolución. Con respecto al manejo quirúrgico cervical inicial, pudimos constatar que un $7,4 \%$ de pacientes con carcinoma epidermoide de cavidad oral que recibieron disección cervical unilateral desarrollaron $\mathrm{MCC}$, frente al $1,8 \%$ de los pacientes que fueron sometidos a disección cervical bilateral de modo primario. Probablemente debido a un menor número muestral, esta asociación no fue significativa en el subgrupo de pacientes con carcinoma epidermoide de lengua, en concordancia con lo referido por otros autores. ${ }^{10}$ En cualquier caso, parece fuera de duda la necesidad de realizar tratamiento cervical bilateral en pacientes con carcinoma epidermoide de la cavidad oral situados en la línea media.6,10,11 Algunos autores han demostrado una asociación estadísticamente significativa entre el estadio $\mathrm{pN}$ y la MCC. Sin embargo, aunque la realización de tratamiento cervical bilateral en pacientes con $\mathrm{N}$ ipsilateral positivo podría derivarse de este estudio, el escaso porcentaje de pacientes que finalmente desarrollan MCC y la morbilidad asociada de este procedimiento, hacen necesaria su aplicación de modo individualizado.

De acuerdo con otras series, la mayoría de los pacientes con MCC desarrollan el evento durante los dos primeros años desde la cirugía. En nuestra serie, $23,8 \%$ de los pacientes que fueron diagnosticados 12 o más meses después de la aparición del tumor primario, desarrollaron MCC, en comparación con el 2,45\% de los pacientes que fueron diagnosticados en el primer año. Siete de 18 pacientes con MCC tras carcinoma epidermoide de la cavidad oral permancece vivo al final del periodo de seguimiento. Solo uno de 9 pacientes con MCC tras carcinoma epidermoide de lengua permanece vivo al final del periodo de seguimiento. Estos datos confirman en la necesidad de realizar un seguimiento estrecho durante este periodo de tiempo.

\section{Conclusiones}

La posibilidad de recoger información de carácter pronóstico con respecto a la aparición de MCC previamente a la cirugía podría mejorar el pronóstico de los pacientes con carcinoma epidermoide de la cavidad oral. Este precepto ayudaría al cirujano a decidir entre diferentes opciones quirúrgicas más o menos agresivas. El retraso diagnóstico mayor de 12 meses desde la aparición del tumor primario, el estadio clínico tumoral IV de la clasificación TNM, el estado $\mathrm{N}$ clínico positivo ipsilateral, el grado histopatológico pobremente diferenciado del tumor primario, los márgenes quirúrgicos menores de $1 \mathrm{~cm}$ en el espécimen resecado, la realización de disección cervical ipsilateral de modo único y la infiltración perineural del tumor primario son factores pronósticos de la aparición de MCC en el carcinoma epidermoide de la cavidad oral. La presencia de metástasis cervicales ipsilaterales en el momento del diagnóstico es predictivo de MCC en el carcinoma epidermoide de cavidad oral. El grado histológico pobremente diferenciado y la ausencia de infla- predictive factor for the appearance of CNM in squamous cell carcinoma of the oral cavity. ${ }^{4,6,9}$ Moreover, the appearance of CNM has been described mainly in the context of simultaneous ipsilateral neck metastasis (INM). With regard to squamous cell carcinoma of the oral cavity, Chow et al 10 demonstrated, in a series of 72 patients, a similar incidence between the appearance of INM $(n=7)$ and CNM $(n=5)$. Our results do not support these findings, as in our series the frequency of $\operatorname{CNM}(5.7 \%, n=18)$ was nearly half the INM rate $(9.1 \%, n=29)$. We were able to demonstrate the presence of INM at diagnosis as a prognostic factor in the appearance of contralateral neck metastasis.

Early diagnosis is fundamental for the purpose of reducing the rate of contralateral neck recurrence. In our series, $23.8 \%$ of patients who were diagnosed after a delay of 12 months or more from the appearance of the primary lesion, presented CNM compared with $2.4 \%$ of patients who were diagnosed with a development of less than 12 months. With regard to the initial neck surgery management, we were able to confirm that $7.4 \%$ of patients with squamous cell carcinoma of the oral cavity who received unilateral neck dissection developed CNM, as opposed to $1.8 \%$ of patients who were subjected to bilateral neck dissection. This association was not significant in the subgroup of patients with squamous cell carcinoma of the tongue, probably as a result of the lower number of these patients, in concordance with reports by other authors. 10 In any event, there is no doubt as to the need for carrying out bilateral neck treatment in patients with midline squamous cell carcinoma of the oral cavity, due to the lower rate of contralateral neck recurrence in these patients. $6,10,11$

Some authors have demonstrated the association with $p<0.05$ between $p N$ stage and CNM. However, although carrying out bilateral neck treatment in patients with positive ipsilateral $N$ could arise from this study, given the scant percentage of patients who finally develop CNM, its application or not has to be established in an individual and personalized fashion.

According to other series, most patients with CNM develop this during the first two years after surgery. Only one patient presented contralateral neck recurrence after this time, as opposed to the remaining $89.9 \%$. These data clearly indicate the need for a close following during this period of time.

To conclude, the possibility of gathering information with a prognostic factor with regard to the appearance of CNM before surgery could improve the prognosis of patients with squamous cell carcinoma of the oral cavity. This rule would help the surgeon decide among the different surgical options that are more or less aggressive. A delay in diagnosis of over 12 months from the appearance of the primary tumor, clinical stage IV tumor by TNM classification, positive ipsilateral clinical $N$ stage, primary tumor with a poorly differentiated histopathologic grade, resection specimen with surgical margins of less than $1 \mathrm{~cm}$, carrying out of ipsilateral 
mación peritumoral son factores pronósticos de MCC en el carcinoma epidermoide de lengua libre. Es preciso un estrecho seguimiento durante los 2 primeros años desde la cirugía, debido a la tasa de recurrencia cervical contralateral aumentada durante este periodo en pacientes con carcinoma epidermoide de cavidad oral.

\section{Bibliografía}

1. Cunningham MJ, Johnson JT, Myers EN, Schramm VL Jr, Thearle PB. Cervical lymph node metastasis after local excision of early squamous cell carcinoma of the oral cavity. Am / Surg 1986;152:361-6.

2. Nyman J, Mercke C, Lindstroem J. Prognostic factors for local control and survival of cancer of the oral tongue: a retrospective analysis of 230 cases in Western Sweden. Acta Oncologica 1993;32:667-6.

3. Kurokawa H, Yamashita Y, Takeda s, Zhang M, Fukuyama H, Takahashi T. Risk factors for late cervical lymph node metastases in patients with stage I or II carcinoma of the tongue. Head Neck 2002;24:731-6.

4. Martin H, Del Valle B, Ehrlich H, Cahan WG. Neck dissection. Cancer 1951;4:44199.

5. Snow GB, Annyas AA, van Sloten EA, et al. Prognostic factors of neck node metastasis. Clin Otolaryngol 1982; 7:185.

6. Woolger JA. Histopathological distribution of cervical lymph node metastasis from intraoral/oropharyngeal squamous cell carcinoma. Br J Oral Maxillofac Surg 1999;37:175-80.

7. Weber PC, Johnson JT, Myers EN. The impact of bilateral neck dissection on the pattern of recurrence and survival in supraglotic carcinoma. Arch Otolaryngol Head Neck 1994;120:703-6.

8. Kurita H, Koite T, Narikawa J, Sakai H, Nakatsuka A, Uehara S, Kobayashi H, kurashina K. Clinical predictors for contralateral neck lymph node metastasis from unilateral squamous cell carcinoma in the oral cavity. Oral Oncol 2004;40:898-903.

9. Northrop M, Fletcher GH, Jesse RH, Lindberg RD. Evolution of neck disease in patients with primary squamous cell carcinoma of the oral tongue, floor of the mouth, and palatine arch, and clinically positive neck nodes neither fixed nor bilateral. Cancer 1972;29:23-30.

10. Chow TL, Chow TK, Chan TT, Yu NF, Fung SC, Lam SH. Contralateral neck recurrence of squamous cell carcinoma of oral cavity and oropharynx. J Oral MaxiIlofac Surg 2004;62:1125-8.

11. Godden DR, Ribeiro NF, Hassanein K, Langton SG. Recurrent neck disease in oral cancer. J Oral Maxillofac Surg 2002;60:748-53.

12. Linberg R. Distribution of cervical lymph node metastasis from squamous cell carcinoma of the upper respiratory and digestive tract. Cancer 1972;6:1446.

13. Fakih AR, Rao RS, Borges AM, et al. Elective versus therapeutic neck dissection in early carcinoma of the oral tongue. Am / Surg 1989;158:309.

14. Weber PC, Johnson JT, Myers EN. The impact of bilateral neck dissection on the pattern of recurrence and survival in supraglotic carcinoma. Arch Otolaryngol Head Neck 1994;120:703-6. neck dissection on its own and perineural infiltration of the primary tumor, are prognostic factors for the appearance of CNM in squamous cell carcinoma of the oral cavity. The presence of ipsilateral pathologic neck nodes at diagnosis is predictive of CNM in squamous cell carcinoma of the oral cavity and tongue. A close following for the first two years after surgery is necessary, due to the increased rate of contralateral neck recurrence during this period in patients with squamous cell carcinoma of the oral cavity. 